\title{
Finding Cultural Differences and Motivation Factors of Foreign Construction Workers
}

\author{
Sangyong Kim¹, Jin-Dong Kim², Honggyu Cho3, Yoonseok Shin', Gwang-Hee Kim* \\ ${ }^{1}$ School of Architecture, Yeungnam University, Gyeongsan-si, South Korea \\ ${ }^{2}$ Department of Architecture, Yeonsung University, Anyang-si, South Korea \\ ${ }^{3}$ Department of Architecture, Bucheon University, Bucheon-si, South Korea \\ ${ }^{4}$ Department of Plant \& Architectural Engineering, Kyonggi University, Suwon-si, South Korea \\ Email: ${ }^{*}$ ghkim@kyonggi.ac.kr
}

Received 23 February 2015; accepted 3 April 2015; published 9 April 2015

Copyright (C) 2015 by authors and Scientific Research Publishing Inc.

This work is licensed under the Creative Commons Attribution International License (CC BY).

http://creativecommons.org/licenses/by/4.0/

(c) (i) Open Access

\section{Abstract}

The rapid inflow of foreign construction workers caused the reduction of labor productivity in the construction industry due to communication problems and cultural differences. This may lead to shortage of productivity and quality reduction. The cultural differences and motivation factors of foreign construction workers must be considered for effective and systematic manpower management. It is necessary to study foreign construction workers' productivity factors that reflect cultural differences and motivation as the productivity and quality of the construction industry are subject to the work efficiency and high dependence of manpower. This study aimed to suggest effective productivity management plan considering cultural differences and motivation factors of foreign construction workers. For this purpose, the desire and motivation factors affecting on Korean workers and foreign construction workers were analyzed and the comparative analysis on the requirements by nationality was carried out. Accordingly, it is expected that this could contribute to the improvement of productivity, construction period, quality, safety and manpower management.

\section{Keywords}

Cultural Difference, Foreign Workers, Motivation, Productivity

\section{Introduction}

Younger workers tend to avoid the construction sector, as it is considered one of the 3D (difficult, dirty, and

${ }^{*}$ Corresponding author.

How to cite this paper: Kim, S., Kim, J.-D., Cho, H., Shin, Y. and Kim, G.-H. (2015) Finding Cultural Differences and Motivation Factors of Foreign Construction Workers. Journal of Building Construction and Planning Research, 3, 35-46.

http://dx.doi.org/10.4236/jbcpr.2015.32005 
dangerous) industries, and as a result, skilled labor is currently provided mostly by aged workers. Against this background, the shortfall in the workforce has led to an increase in the employment of foreign laborers. However, the rapid increase in the number of foreign construction workers has led to problems such as decreased labor productivity, more accidents, and inferior quality or faulty construction due to language barriers and cultural differences between field managers and foreign workers [1]. In addition, beyond the economic realm, there are issues related to the settlement and adjustment of foreign workers, which must be dealt with from either a social or a diplomatic perspective [2]. Failure to address these problems may lead to social issues in the future. To be more specific, foreign construction workers are often exposed to different cultural settings, and suffer hardships in their new country such as lack of communication with their colleagues and failure to adjust to the work environment [3]-[5]. Thus, there is an urgent need for research to improve the construction productivity of foreign laborers by management plan, based on an understanding of the cultural differences of laborers from different countries.

For this reason, the scope of this study involves a comparative analysis of the impact of cultural differences and the relative importance of certain factors for productivity. To undertake the study, we identified motivation factors that were influenced by the cultural differences of the laborers, and their effect on productivity.

\section{Methodology}

To derive productivity factors that could be influenced by cultural diversity, we reviewed previous studies related to Maslow's hierarchy of needs, Alderfer's Existence Relatedness Growth (ERG) needs theory, Herzberg's two-factor theory, Murray's needs and pressure theory. After excluding redundant productivity factors mentioned in related theories and previous studies, 34 productivity factors were derived. Participants were recruited from construction sites in Seoul and Gyeonggi-do, and restricted to nationalities that constitute a large proportion of immigrants to Korea based on the Korea Immigration Service records. Either face-to-face or mail interviews were conducted with the selected foreign laborers. Based on the results of a preliminary survey of field technicians with at least 15 years of work experience, a final set of 27 factors was included in the questionnaire: 5 economic factors, 11 social factors, and 11 psychological factors. Items were scored on a five-point Likert scale, and the answers were analyzed to establish the relative importance of each factor. To determine whether the importance of the factors differed by nationality, an analysis of variance (ANOVA) test was conducted, and a correlation analysis was performed to understand the relationships between the various factors. These statistical analyses were performed using SPSS.

\section{Motivation Theory}

\subsection{Human Needs and Behavior}

Human beings have numerous needs, which continue to be stimulated by intrinsic and extrinsic factors. Needs provoked by a stimulus are directly related to human behaviors, but the behaviors cannot be explained purely as a process of satisfying human needs, as behavioral options are often in conflict with or compromise environmental factors in the course of the needs-satisfying process. The interaction of a human's internal needs with factors in the external environment is a complex process that not only affects the environment that the person is in, and has an impact on his/her needs, but also has a simultaneous influence on several other factors, including attitudes and values. A person's participation in an organization has two important aspects: one is the satisfaction of personal needs, and the other is the attainment of something that is only possible in cooperation with others. To achieve optimal organizational performance, it is important to understand the individual behavioral motivation of each member of the organization, and then use this motivation to stimulate the collaborative efforts of the members.

\subsection{Motivation Level and Motivation}

Motivation is an explanatory concept for a behavior. The motivation level is determined by the interaction between a person and the environment or, more specifically, the interaction of personal factors with various environmental factors. The needs theories that hold that a person's motivation level is determined by personal factors include Maslow's hierarchy of needs and Alderfer's ERG theory. The theories that emphasize environmental factors include Herzberg's job enrichment theory and Skinner's organizational behavior modification theory. 
Theories that stress the interaction between the individual and the environment include Atkinson's achievement motivation theory. In terms of work, the higher the motivation, the more positively job performance is affected. However, the job performance level is generally affected by a composite of factors beyond the motivation level, including personal and organizational capability or competence, personality traits, and role perception [6]. Work motivation to perform one's job refers to the conditions that trigger behaviors related to the job in the working environment, and which make the individual orient himself or herself toward the goal and maintain this stance. When there are unmet needs, the individual responds to inducement or goal motivation that can satisfy his/her needs.

\section{Motivation Factors Related to Productivity}

To identify motivation factors related to productivity, we summarize the motivation factors found in Maslow's hierarchy of needs theory, Alderfer's ERG theory, Herzberg's motivation-hygiene theory, and Murray's needs and pressure theory. Furthermore, the factors influencing productivity found in previous studies from both Korea and the rest of the world. After the exclusion of repeated items, the list of productivity factors identified by previous research comprises 34 factors. The preliminary interview was carried out to determine the criteria for the years of work experience of the experts and the number of items to be selected, which hinged entirely on the opinions of the experts interviewed. Based on the results of the aforementioned face-to-face interviews, 30 experts with at least 10 years of field experience were selected for the preliminary study. Participants were asked to identify the five motivation factors that were most important in their view for productivity. This study is divided the productivity-related factors derived from the preliminary study into economic, social, and psychological factors. A factor was selected if at least eight participants listed it among the five most important items. As a result, 27 productivity-related factors were selected through the preliminary study, composed of five economic factors, 11 social factors, and 11 psychological factors. Table 1 shows the factors selected.

\section{Cultural Differences in Motivation Factors}

\subsection{Factor Importance by Nationality}

A statistical analysis was performed to determine the order of importance of the productivity-related factors for workers of different nationalities after dividing them into economic, social, and psychological factors by nationality, ANOVA and Scheffé's tests were performed. As shown in Table 2, the ANOVA test revealed statistically significant differences between nationalities in the importance of economic factors. Philippine workers (3.96) and Mongolian workers (3.86) were shown to give relatively high importance to these factors in the ANOVA results, whereas there were no significant differences in Scheffé's test results by nationality.

In terms of social factors, there were no significant differences in ANOVA results, but significant differences were found in terms of psychological factors (see Table A1). In terms of timely payment dates, Mongolian workers were found to regard this factor as more important than Thai workers, and this difference was statistically significant. In terms of amount of pay, there were no statistically significant differences, whereas there were statistically significant differences in terms of payment of incentive, with Philippine workers (3.96) giving this factor a relatively higher importance than workers from other countries. However, there were no statistically significant differences in Scheffé's test results. In terms of employment guarantee, there were no significant differences in the ANOVA results, although results for Philippine workers (4.00) were comparatively higher, and there were no statistically significant differences in Scheffé's test results. In terms of welfare, social status, and social stability, there were statistically significant differences. In terms of "company policy," "social security

Table 1. Selected motivation factors related to productivity.

Economical factors

Social factors

Psychological factors
Amount of pays, incentive, payment date, welfare, employment guarantee

Social security insurance, participation in decision making, company policy, management policy, social recognition, social life opportunity, job autonomy, self-development opportunity, social status, cultural differences, job discretion

Working conditions, sense of belonging, working conditions, achievement, relationship with colleagues, satisfaction, relationship with managers, possibility of growth, sense of responsibility, equal promotion opportunity, challenge 
Table 2. Nationalities in the importance of economic factors.

\begin{tabular}{|c|c|c|c|c|c|c|c|}
\hline Factors & Nationality & $\mathrm{N}$ & M & SD & $\mathrm{F}$ & $\mathrm{P}$ & Scheffe \\
\hline \multirow{8}{*}{$\begin{array}{l}\text { Payment } \\
\text { date }\end{array}$} & Philippine (a) & 30 & 3.90 & 1.06 & \multirow{8}{*}{4.101} & \multirow{8}{*}{0.000} & \multirow{8}{*}{$d>f$} \\
\hline & Vietnamese (b) & 165 & 3.45 & 1.13 & & & \\
\hline & Chinese (c) & 75 & 3.53 & 1.33 & & & \\
\hline & Mongolian (d) & 56 & 4.09 & 1.23 & & & \\
\hline & Korean Chinese (e) & 157 & 3.75 & 1.12 & & & \\
\hline & Thai (f) & 68 & 3.31 & 1.31 & & & \\
\hline & Korean (g) & 504 & 3.75 & 1.14 & & & \\
\hline & Total & 1055 & 3.68 & 1.17 & & & \\
\hline \multirow{8}{*}{$\begin{array}{l}\text { Amount } \\
\text { of pay }\end{array}$} & Philippine & 30 & 4.23 & 0.86 & \multirow{8}{*}{1.371} & \multirow{8}{*}{0.223} & \multirow{8}{*}{-} \\
\hline & Vietnamese & 165 & 3.75 & 1.04 & & & \\
\hline & Chinese & 75 & 3.91 & 1.15 & & & \\
\hline & Mongolian & 56 & 4.04 & 1.16 & & & \\
\hline & Korean Chinese & 157 & 3.94 & 1.05 & & & \\
\hline & Thai & 68 & 3.84 & 1.10 & & & \\
\hline & Korean & 504 & 3.88 & 1.00 & & & \\
\hline & Total & 1055 & 3.89 & 1.04 & & & \\
\hline \multirow{8}{*}{ Incentive } & Philippine & 30 & 3.97 & 0.72 & \multirow{8}{*}{2.146} & \multirow{8}{*}{0.046} & \multirow{8}{*}{$\begin{array}{c}\text { No } \\
\text { difference }\end{array}$} \\
\hline & Vietnamese & 165 & 3.33 & 1.01 & & & \\
\hline & Chinese & 75 & 3.71 & 1.24 & & & \\
\hline & Mongolian & 56 & 3.64 & 1.02 & & & \\
\hline & Korean Chinese & 157 & 3.53 & 1.12 & & & \\
\hline & Thai & 68 & 3.62 & 1.16 & & & \\
\hline & Korean & 504 & 3.60 & 1.19 & & & \\
\hline & Total & 1055 & 3.57 & 1.14 & & & \\
\hline \multirow{8}{*}{$\begin{array}{c}\text { Employment } \\
\text { guarantee }\end{array}$} & Philippine & 30 & 4.00 & 0.87 & \multirow{8}{*}{3.016} & \multirow{8}{*}{0.006} & \multirow{8}{*}{$\begin{array}{c}\text { No } \\
\text { difference }\end{array}$} \\
\hline & Vietnamese & 165 & 3.41 & 1.07 & & & \\
\hline & Chinese & 75 & 3.37 & 1.30 & & & \\
\hline & Mongolian & 56 & 3.80 & 1.18 & & & \\
\hline & Korean Chinese & 157 & 3.69 & 1.16 & & & \\
\hline & Thai & 68 & 3.38 & 1.33 & & & \\
\hline & Korean & 504 & 3.66 & 1.13 & & & \\
\hline & Total & 1055 & 3.61 & 1.15 & & & \\
\hline
\end{tabular}

insurance,” and “job autonomy,” there were statistically significant differences for the ANOVA results, indicating that Mongolian workers found these factors more important overall, but no statistically significant differences were shown in the Scheffé's test results.

To understand the differences in psychological factors by nationality, ANOVA and Scheffé's tests were con- 
ducted (see Table A2). With the exception of “interpersonal relationship with managers," there were statistically significant differences for all items in the ANOVA results. However, there were no significant differences found for several items in Scheffé's test, conducted for post-hoc comparisons. While ANOVA results are statistically reliable in general, reliability increases when the differences are also statistically significant in Scheffé's test. In addition, when seven groups are compared, as was done in this study, the reliability of ANOVA can be lower; therefore, the analytical results for which both ANOVA and Scheffé's test were found to have statistical significance were listed first in this study. Scheffé's test results with statistical significance were found for "challenges in the job," which Mongolian workers rated as more important than Korean Chinese workers, and with regard to "relationship with colleagues," for which Vietnamese, Mongolian, and Korean workers scored higher than Chinese workers. In terms of "sense of belonging to the company," Vietnamese and Mongolian workers rated this higher than Korean Chinese workers, and in terms of "sense of responsibility for the job," Mongolian workers rated this higher than did Korean Chinese and Thai workers.

\subsection{Survey Analysis Results}

There were no statistically significant differences between Korean workers and foreign workers in economic, psychological, and social factors overall. However, when subitems were analyzed, differences between Korean and foreign workers were revealed. In particular, in terms of social factors, there were no significant differences found in the higher-level category, but there were significant differences in subitems such as "social security insurance," "participation in decision making," and "cultural differences." Foreign workers considered "social security insurance" and "cultural differences" more important than did Korean workers, whereas Korean workers assessed "participation in decision making" as more important than did foreign workers. By nationality, there were differences between Korean Chinese and Korean workers in the domain of psychological factors. More specifically, Korean Chinese workers evaluated psychological factors as more important than did Korean workers. In economic factors, there were significant differences in Vietnamese and Philippine workers compared with Korean workers, with Vietnamese workers attaching a relatively lower importance to these factors, whereas Philippine workers considered them as more important compared with Korean workers. Finally, in the regional analysis between the workers from Southeast Asia (Vietnamese, Philippine, and Thai workers) and workers from East Asia (Korean, Korean Chinese, Chinese, and Mongolian workers), statistically significant differences were found in economic factors, showing that workers from East Asia considered economic factors as more important than did workers from Southeast Asia.

\section{Conclusions and Future Work}

This study was motivated by the view that cultural differences should be taken into account in the management of Korean and foreign workers on construction sites. Taking cultural differences into account, motivation factors that could have an impact on productivity were determined and broken down by nationality, based on the analysis results. The results can be utilized as follows. First, as a response to the trend whereby an increasing number of both skilled and unskilled foreign workers are entering the construction sector, our results provide a basis for developing more efficient management plans for the foreign workers. Second, the findings of this research can be utilized as fundamental data to stimulate social awareness and build an appropriate systemic device. Third, the results can also be utilized as specification and operational data for a management plan based on cultural differences between foreign workers in the construction industry.

Building on the findings of this research, future studies should develop a more generalized management plan to improve productivity. There are limitations to this study. First, factors that are more diverse should be analyzed in addition to the motivation factors. Second, this study focused only on the current situation, as it was intended as a fundamental study of the analysis of productivity factors according to the cultural differences between foreign workers. Third, due to the language barrier, some foreign workers had difficulties understanding and answering some of the questions. Therefore, based on the limitations of this study, the following aspects should be investigated further in the future. First, a more objective and concrete systemic and social management system should be studied to establish the management of foreign workers. Second, a study through direct interviews with foreign workers is needed to help construction companies that hire foreign workers to acquire and cultivate multicultural sensitivity in order to cope with cultural differences. Finally, a more concrete, systemic utilization plan for more efficient workforce management and a plan to optimize working conditions should be examined. 


\section{Acknowledgements}

This research was supported by Basic Science Research Program through the National Research Foundation of Korea (NRF) funded by the Ministry of Education (2010-0021520).

\section{References}

[1] Go, S.G., Park, M.K., Kim, Y.S., Lim, C.W. and Kim, C.D. (2009) A Study about the Plan of Foreign Construction Worker's Safety Management. Proceedings of Korea Institute of Construction Engineering and Management, November 2001, 36-39.

[2] Seymen, O.A. (2006) The Cultural Diversity Phenomenon in Organisations and Different Approaches for Effective Cultural Diversity Management: A Literary Review. Cross Cultural Management: An International Journal, 13, 296315. http://dx.doi.org/10.1108/13527600610713404

[3] Fontaine, R. (2007) Cross-Cultural Management: Six Perspectives. Cross Cultural Management: An International Journal, 14, 125-135. http://dx.doi.org/10.1108/13527600710745732

[4] Ascalon, M.E., Schleicher, D.J. and Born, M.P. (2008) Cross-Cultural Social Intelligence: An Assessment for Employees Working in Cross-National Contexts. Cross Cultural Management: An International Journal, 15, 109-130. http://dx.doi.org/10.1108/13527600810870570

[5] Dong, K. and Liu, Y. (2010) Cross-Cultural Management in China. Cross Cultural Management: An International Journal, 17, 223-243. http://dx.doi.org/10.1108/13527601011068333

[6] McCormick, E.J. and Ilgen, D.R. (1980) Industrial Psychology. 7th Edition, Prentice-Hall, Englewood Cliffs. 


\section{Appendix}

Table A1. Nationalities in the importance of social factors.

\begin{tabular}{|c|c|c|c|c|c|c|c|}
\hline Factors & Nationality & $\mathrm{N}$ & M & SD & $\mathrm{F}$ & $\mathrm{P}$ & Scheffe \\
\hline \multirow{9}{*}{ Welfare } & Philippine & 30 & 3.70 & 0.99 & \multirow{9}{*}{0.971} & \multirow{9}{*}{0.443} & \multirow{9}{*}{ - } \\
\hline & Vietnamese & 165 & 3.54 & 1.06 & & & \\
\hline & Chinese & 75 & 3.39 & 1.31 & & & \\
\hline & Mongolian & 56 & 3.71 & 1.06 & & & \\
\hline & & & & & & & \\
\hline & Korean Chinese & 157 & 3.46 & 1.33 & & & \\
\hline & Thai & 68 & 3.41 & 1.26 & & & \\
\hline & Korean & 504 & 3.60 & 1.18 & & & \\
\hline & Total & 1055 & 3.55 & 1.19 & & & \\
\hline \multirow{9}{*}{ Social status } & Philippine & 30 & 3.10 & 1.18 & \multirow{9}{*}{1.432} & \multirow{9}{*}{0.199} & \multirow{9}{*}{ - } \\
\hline & Vietnamese & 165 & 3.11 & 1.04 & & & \\
\hline & Chinese & 75 & 2.99 & 1.44 & & & \\
\hline & Mongolian & 56 & 3.34 & 1.07 & & & \\
\hline & & & & & & & \\
\hline & Korean Chinese & 157 & 3.34 & 1.24 & & & \\
\hline & Thai & 68 & 3.04 & 1.32 & & & \\
\hline & Korean & 504 & 3.23 & 1.09 & & & \\
\hline & Total & 1055 & 3.20 & 1.15 & & & \\
\hline \multirow{8}{*}{$\begin{array}{c}\text { Social } \\
\text { recognition }\end{array}$} & Philippine & 30 & 3.03 & 1.16 & \multirow{8}{*}{1.156} & \multirow{8}{*}{0.328} & \multirow{8}{*}{ - } \\
\hline & Vietnamese & 165 & 3.16 & 1.00 & & & \\
\hline & Chinese & 75 & 3.04 & 1.36 & & & \\
\hline & Mongolian & 56 & 3.20 & 1.10 & & & \\
\hline & Korean Chinese & 157 & 3.30 & 1.16 & & & \\
\hline & Thai & 68 & 3.35 & 1.09 & & & \\
\hline & Korean & 504 & 3.29 & 1.06 & & & \\
\hline & Total & 1055 & 3.25 & 1.10 & & & \\
\hline \multirow{8}{*}{$\begin{array}{l}\text { Company } \\
\text { policy }\end{array}$} & Philippine & 30 & 2.97 & 1.03 & \multirow{8}{*}{2.290} & \multirow{8}{*}{0.033} & \multirow{8}{*}{$\begin{array}{c}\text { No } \\
\text { difference }\end{array}$} \\
\hline & Vietnamese & 165 & 3.52 & 0.99 & & & \\
\hline & Chinese & 75 & 3.43 & 1.34 & & & \\
\hline & Mongolian & 56 & 3.75 & 1.24 & & & \\
\hline & Korean Chinese & 157 & 3.44 & 1.21 & & & \\
\hline & Thai & 68 & 3.32 & 1.32 & & & \\
\hline & Korean & 504 & 3.34 & 1.07 & & & \\
\hline & Total & 1055 & 3.40 & 1.13 & & & \\
\hline
\end{tabular}




\section{Continued}

\begin{tabular}{|c|c|c|c|c|c|c|c|}
\hline \multirow{8}{*}{$\begin{array}{c}\text { Social } \\
\text { security } \\
\text { insurance }\end{array}$} & Philippine & 30 & 3.60 & 0.97 & \multirow{8}{*}{2.904} & \multirow{8}{*}{1.008} & \multirow{8}{*}{$\begin{array}{c}\text { No } \\
\text { difference }\end{array}$} \\
\hline & Vietnamese & 165 & 3.52 & 1.03 & & & \\
\hline & Chinese & 75 & 3.37 & 1.36 & & & \\
\hline & Mongolian & 56 & 3.96 & 1.14 & & & \\
\hline & Korean Chinese & 157 & 3.68 & 1.18 & & & \\
\hline & Thai & 68 & 3.41 & 1.19 & & & \\
\hline & Korean & 504 & 3.43 & 1.05 & & & \\
\hline & Total & 1055 & 3.51 & 1.11 & & & \\
\hline \multirow{8}{*}{$\begin{array}{c}\text { Job } \\
\text { autonomy }\end{array}$} & Philippine & 30 & 3.37 & 1.10 & \multirow{8}{*}{3.092} & \multirow{8}{*}{0.005} & \multirow{8}{*}{$\begin{array}{c}\text { No } \\
\text { difference }\end{array}$} \\
\hline & Vietnamese & 165 & 3.19 & 0.97 & & & \\
\hline & Chinese & 75 & 3.00 & 1.40 & & & \\
\hline & Mongolian & 56 & 3.64 & 0.88 & & & \\
\hline & Korean Chinese & 157 & 3.07 & 1.17 & & & \\
\hline & Thai & 68 & 3.38 & 1.18 & & & \\
\hline & Korean & 504 & 3.29 & 1.02 & & & \\
\hline & Total & 1055 & 3.25 & 1.08 & & & \\
\hline \multirow{8}{*}{$\begin{array}{l}\text { Self-development } \\
\text { opportunity }\end{array}$} & Philippine & 30 & 3.50 & 1.31 & \multirow{8}{*}{3.331} & \multirow{8}{*}{0.003} & \multirow{8}{*}{$\begin{array}{c}\text { No } \\
\text { difference }\end{array}$} \\
\hline & Vietnamese & 165 & 3.30 & 1.07 & & & \\
\hline & Chinese & 75 & 2.91 & 1.26 & & & \\
\hline & Mongolian & 56 & 3.61 & 0.91 & & & \\
\hline & Korean Chinese & 157 & 3.07 & 1.19 & & & \\
\hline & Thai & 68 & 3.06 & 1.10 & & & \\
\hline & Korean & 504 & 3.19 & 1.06 & & & \\
\hline & Total & 1055 & 3.19 & 1.11 & & & \\
\hline \multirow{8}{*}{$\begin{array}{l}\text { Participation } \\
\text { in decision } \\
\text { making }\end{array}$} & Philippine & 30 & 3.47 & 1.14 & \multirow{8}{*}{3.265} & \multirow{8}{*}{0.003} & \multirow{8}{*}{$\begin{array}{c}\text { No } \\
\text { difference }\end{array}$} \\
\hline & Vietnamese & 165 & 2.93 & 1.10 & & & \\
\hline & Chinese & 75 & 2.88 & 1.28 & & & \\
\hline & Mongolian & 56 & 3.39 & 0.95 & & & \\
\hline & Korean Chinese & 157 & 3.03 & 1.24 & & & \\
\hline & Thai & 68 & 3.21 & 1.31 & & & \\
\hline & Korean & 504 & 3.23 & 1.06 & & & \\
\hline & Total & 1055 & 3.14 & 1.13 & & & \\
\hline
\end{tabular}




\section{Continued}

\begin{tabular}{|c|c|c|c|c|c|c|c|}
\hline \multirow{8}{*}{$\begin{array}{c}\text { Job } \\
\text { discretion }\end{array}$} & Philippine & 30 & 3.10 & 1.30 & \multirow{8}{*}{2.143} & \multirow{8}{*}{0.046} & \multirow{8}{*}{$\begin{array}{c}\text { No } \\
\text { difference }\end{array}$} \\
\hline & Vietnamese & 165 & 3.15 & 1.16 & & & \\
\hline & Chinese & 75 & 3.39 & 1.28 & & & \\
\hline & Mongolian & 56 & 3.46 & 1.06 & & & \\
\hline & Korean Chinese & 157 & 3.01 & 1.28 & & & \\
\hline & Thai & 68 & 3.94 & 6.39 & & & \\
\hline & Korean & 504 & 3.21 & 1.00 & & & \\
\hline & Total & 1055 & 3.24 & 1.95 & & & \\
\hline \multirow{8}{*}{$\begin{array}{c}\text { Cultural } \\
\text { differences }\end{array}$} & Philippine (a) & 30 & 3.50 & 1.04 & \multirow{8}{*}{10.017} & \multirow{8}{*}{0.000} & \multirow{8}{*}{$\begin{array}{c}\mathrm{b}>\mathrm{c}, \mathrm{d}, \mathrm{e}, \mathrm{g} \\
\mathrm{f}>\mathrm{c}, \mathrm{d}\end{array}$} \\
\hline & Vietnamese (b) & 165 & 3.67 & 1.01 & & & \\
\hline & Chinese (c) & 75 & 2.96 & 1.36 & & & \\
\hline & Mongolian (d) & 56 & 2.68 & 1.22 & & & \\
\hline & Korean Chinese (e) & 157 & 3.22 & 1.37 & & & \\
\hline & Thai (f) & 68 & 3.63 & 1.13 & & & \\
\hline & Korean (g) & 504 & 3.13 & 0.95 & & & \\
\hline & Total & 1055 & 3.24 & 1.12 & & & \\
\hline \multirow{8}{*}{$\begin{array}{l}\text { Management } \\
\text { policy }\end{array}$} & Philippine (a) & 30 & 3.03 & 1.22 & \multirow{8}{*}{3.501} & \multirow{8}{*}{0.002} & \multirow{8}{*}{$c>f$} \\
\hline & Vietnamese (b) & 165 & 3.11 & 1.07 & & & \\
\hline & Chinese (c) & 75 & 3.59 & 1.28 & & & \\
\hline & Mongolian (d) & 56 & 3.52 & 1.03 & & & \\
\hline & Korean Chinese (e) & 157 & 3.28 & 1.21 & & & \\
\hline & Thai (f) & 68 & 2.90 & 1.17 & & & \\
\hline & Korean (g) & 504 & 3.21 & 1.05 & & & \\
\hline & Total & 1055 & 3.22 & 1.12 & & & \\
\hline \multirow{8}{*}{$\begin{array}{c}\text { Equal } \\
\text { opportunity }\end{array}$} & Philippine (a) & 30 & 4.40 & 1.01 & \multirow{8}{*}{5.581} & \multirow{8}{*}{0.000} & \multirow{8}{*}{$\mathrm{a}>\mathrm{b}, \mathrm{c}, \mathrm{e}, \mathrm{f}, \mathrm{g}$} \\
\hline & Vietnamese (b) & 165 & 3.16 & 0.97 & & & \\
\hline & Chinese (c) & 75 & 2.93 & 1.27 & & & \\
\hline & Mongolian (d) & 56 & 3.32 & 0.92 & & & \\
\hline & Korean Chinese (e) & 157 & 2.83 & 1.12 & & & \\
\hline & Thai (f) & 68 & 3.16 & 1.25 & & & \\
\hline & Korean (g) & 504 & 3.21 & 1.06 & & & \\
\hline & Total & 1055 & 3.16 & 1.46 & & & \\
\hline
\end{tabular}


Table A2. Nationalities in the importance of psychological factors.

\begin{tabular}{|c|c|c|c|c|c|c|c|}
\hline Factors & Nationality & $\mathrm{N}$ & M & SD & F & $\mathrm{P}$ & Scheffe \\
\hline \multirow{8}{*}{$\begin{array}{l}\text { Working } \\
\text { condition }\end{array}$} & Philippine & 30 & 3.60 & 1.07 & \multirow{8}{*}{2.457} & \multirow{8}{*}{0.023} & \multirow{8}{*}{$\begin{array}{c}\text { No } \\
\text { difference }\end{array}$} \\
\hline & Vietnamese & 165 & 3.75 & 1.00 & & & \\
\hline & Chinese & 75 & 3.49 & 1.23 & & & \\
\hline & Mongolian & 56 & 4.14 & 1.05 & & & \\
\hline & Korean Chinese & 157 & 3.73 & 1.10 & & & \\
\hline & Thai & 68 & 3.51 & 1.28 & & & \\
\hline & Korean & 504 & 3.67 & 1.09 & & & \\
\hline & Total & 1055 & 3.69 & 1.10 & & & \\
\hline \multirow{8}{*}{$\begin{array}{c}\text { Sense of } \\
\text { belonging }\end{array}$} & Philippine (a) & 30 & 3.67 & 1.03 & \multirow{8}{*}{4.610} & \multirow{8}{*}{0.000} & \multirow{8}{*}{$b, d>e$} \\
\hline & Vietnamese (b) & 165 & 3.61 & 0.87 & & & \\
\hline & Chinese (c) & 75 & 3.16 & 1.34 & & & \\
\hline & Mongolian (d) & 56 & 3.75 & 0.88 & & & \\
\hline & Korean Chinese (e) & 157 & 3.15 & 1.19 & & & \\
\hline & Thai (f) & 68 & 3.28 & 1.31 & & & \\
\hline & Korean (g) & 504 & 3.44 & 1.04 & & & \\
\hline & Total & 1055 & 3.41 & 1.08 & & & \\
\hline \multirow{8}{*}{ Satisfaction } & Philippine & 30 & 3.53 & 0.94 & \multirow{8}{*}{3.037} & \multirow{8}{*}{0.006} & \multirow{8}{*}{$\begin{array}{c}\text { No } \\
\text { difference }\end{array}$} \\
\hline & Vietnamese & 165 & 3.44 & 1.00 & & & \\
\hline & Chinese & 75 & 3.08 & 1.36 & & & \\
\hline & Mongolian & 56 & 3.71 & 0.80 & & & \\
\hline & Korean Chinese & 157 & 3.27 & 1.28 & & & \\
\hline & Thai & 68 & 3.15 & 1.34 & & & \\
\hline & Korean & 504 & 3.40 & 0.91 & & & \\
\hline & Total & 1055 & 3.37 & 1.06 & & & \\
\hline \multirow{8}{*}{ Achievement } & Philippine & 30 & 3.60 & 1.10 & \multirow{8}{*}{2.846} & \multirow{8}{*}{0.009} & \multirow{8}{*}{$\begin{array}{c}\text { No } \\
\text { difference }\end{array}$} \\
\hline & Vietnamese & 165 & 3.45 & 0.98 & & & \\
\hline & Chinese & 75 & 3.27 & 1.24 & & & \\
\hline & Mongolian & 56 & 3.71 & 0.80 & & & \\
\hline & Korean Chinese & 157 & 3.18 & 1.20 & & & \\
\hline & Thai & 68 & 3.22 & 1.29 & & & \\
\hline & Korean & 504 & 3.40 & 0.92 & & & \\
\hline & Total & 1055 & 3.38 & 1.03 & & & \\
\hline
\end{tabular}




\section{Continued}

\begin{tabular}{|c|c|c|c|c|c|c|c|}
\hline \multirow{8}{*}{$\begin{array}{l}\text { Sense of } \\
\text { responsibility }\end{array}$} & Philippine (a) & 30 & 3.73 & 0.87 & \multirow{8}{*}{5.620} & \multirow{8}{*}{0.000} & \multirow{8}{*}{$d>e, f$} \\
\hline & Vietnamese (b) & 165 & 3.51 & 1.12 & & & \\
\hline & Chinese (c) & 75 & 3.19 & 1.42 & & & \\
\hline & Mongolian (d) & 56 & 3.80 & 0.98 & & & \\
\hline & Korean Chinese (e) & 157 & 3.18 & 1.23 & & & \\
\hline & Thai (f) & 68 & 3.04 & 1.37 & & & \\
\hline & Korean (g) & 504 & 3.52 & 0.95 & & & \\
\hline & Total & 1055 & 3.43 & 1.10 & & & \\
\hline \multirow{8}{*}{$\begin{array}{c}\text { Equal } \\
\text { Promotion } \\
\text { opportunity }\end{array}$} & Philippine & 30 & 3.10 & 1.21 & \multirow{8}{*}{2.206} & \multirow{8}{*}{0.040} & \multirow{8}{*}{$\begin{array}{c}\text { No } \\
\text { difference }\end{array}$} \\
\hline & Vietnamese & 165 & 3.26 & 1.16 & & & \\
\hline & Chinese & 75 & 2.99 & 1.31 & & & \\
\hline & Mongolian & 56 & 3.43 & 0.93 & & & \\
\hline & Korean Chinese & 157 & 2.97 & 1.31 & & & \\
\hline & Thai & 68 & 2.90 & 1.36 & & & \\
\hline & Korean & 504 & 3.00 & 1.18 & & & \\
\hline & Total & 1055 & 3.06 & 1.21 & & & \\
\hline \multirow{8}{*}{ Challenge } & Philippine (a) & 30 & 3.07 & 1.05 & \multirow{8}{*}{3.299} & \multirow{8}{*}{0.003} & \multirow{8}{*}{$d>e$} \\
\hline & Vietnamese (b) & 165 & 3.18 & 1.06 & & & \\
\hline & Chinese (c) & 75 & 3.32 & 1.26 & & & \\
\hline & Mongolian (d) & 56 & 3.54 & 0.83 & & & \\
\hline & Korean Chinese (e) & 157 & 2.90 & 1.29 & & & \\
\hline & Thai (f) & 68 & 2.85 & 1.35 & & & \\
\hline & Korean (g) & 504 & 3.14 & 1.12 & & & \\
\hline & Total & 1055 & 3.12 & 1.15 & & & \\
\hline \multirow{8}{*}{$\begin{array}{l}\text { Possibility } \\
\text { of growth }\end{array}$} & Philippine (a) & 30 & 3.83 & 0.99 & \multirow{8}{*}{6.374} & \multirow{8}{*}{0.000} & \multirow{8}{*}{$a>e, f$} \\
\hline & Vietnamese (b) & 165 & 3.23 & 1.05 & & & \\
\hline & Chinese (c) & 75 & 3.07 & 1.24 & & & \\
\hline & Mongolian (d) & 56 & 3.68 & 0.90 & & & \\
\hline & Korean Chinese (e) & 157 & 2.89 & 1.24 & & & \\
\hline & Thai (f) & 68 & 2.94 & 1.38 & & & \\
\hline & Korean (g) & 504 & 3.28 & 1.10 & & & \\
\hline & Total & 1055 & 3.22 & 1.15 & & & \\
\hline \multirow{8}{*}{$\begin{array}{l}\text { Relationship } \\
\text { with } \\
\text { colleagues }\end{array}$} & Philippine (a) & 30 & 3.80 & 1.00 & \multirow{8}{*}{5.530} & \multirow{8}{*}{0.000} & \multirow{8}{*}{ b, d, g > c } \\
\hline & Vietnamese (b) & 165 & 3.64 & 0.97 & & & \\
\hline & Chinese (c) & 75 & 2.97 & 1.45 & & & \\
\hline & Mongolian (d) & 56 & 3.77 & 1.13 & & & \\
\hline & Korean Chinese (e) & 157 & 3.29 & 1.30 & & & \\
\hline & Thai (f) & 68 & 3.44 & 1.23 & & & \\
\hline & Korean (g) & 504 & 3.56 & 0.97 & & & \\
\hline & Total & 1055 & 3.50 & 1.10 & & & \\
\hline
\end{tabular}




\begin{tabular}{|c|c|c|c|c|c|c|c|}
\hline \multicolumn{8}{|l|}{ Continued } \\
\hline \multirow{8}{*}{$\begin{array}{l}\text { Relationship } \\
\text { with } \\
\text { managers }\end{array}$} & Philippine & 30 & 3.73 & 0.94 & \multirow{8}{*}{1.913} & \multirow{8}{*}{0.076} & \multirow{8}{*}{-} \\
\hline & Vietnamese & 165 & 3.61 & 1.00 & & & \\
\hline & Chinese & 75 & 3.33 & 1.39 & & & \\
\hline & Mongolian & 56 & 3.79 & 1.00 & & & \\
\hline & Korean Chinese & 157 & 3.38 & 1.26 & & & \\
\hline & Thai & 68 & 3.44 & 1.20 & & & \\
\hline & Korean & 504 & 3.52 & 0.95 & & & \\
\hline & Total & 1055 & 3.52 & 1.07 & & & \\
\hline \multirow{8}{*}{$\begin{array}{l}\text { Working } \\
\text { conditions }\end{array}$} & Philippine & 30 & 3.70 & 1.06 & \multirow{8}{*}{3.685} & \multirow{8}{*}{0.001} & \multirow{8}{*}{$\begin{array}{c}\text { No } \\
\text { difference }\end{array}$} \\
\hline & Vietnamese & 165 & 3.62 & 1.06 & & & \\
\hline & Chinese & 75 & 3.16 & 1.39 & & & \\
\hline & Mongolian & 56 & 3.82 & 0.81 & & & \\
\hline & Korean Chinese & 157 & 3.39 & 1.16 & & & \\
\hline & Thai & 68 & 3.72 & 1.02 & & & \\
\hline & Korean & 504 & 3.62 & 1.00 & & & \\
\hline & Total & 1055 & 3.57 & 1.07 & & & \\
\hline
\end{tabular}

